\title{
'N BEDRYFSIELKUNDIGE ONDERSOEK NA DIE VERBRUIKERBEELD VAN HANDELSBANKE IN SUID-AFRIKA
}

\author{
H.I.J. SPOELSTRA
}

DEPARTEMENT BEDRYFSIELKUNDE UNIVERSITEIT VAN SUID-AFRIKA

\section{SUMMARY}

In this investigation the hypothesis is tested that every commercial bank has a unique and differentiated consumer image. A factor analytical study is performed to develop a semantic differential by means of which consumer image scales can be established. The results indicate that commercial banks can be evaluated in terms of 14 dimensions. The hypothesis is thus confirmed and a method is developed which can be applied to a variety of research objectives.

\section{PROBLEEMSTELLING}

'n Interessante verskynsel van die afgelope paar dekades is die ontwikkeling van 'n belangstellingsterrein of vakgebied waarna moontlik verwys kan word as die wetenskap van die verbruiker. Daar kan vandag min twyfel oor bestaan dat akademiese en professionele belangstelling in die verbruiker aan die toeneem is en dat sekere metodes, empiriese prosedures en teorieë eie aan die "verbruikerwetenskap", in "n toenemende mate ontwikkel word.

Die verbruikersielkunde as subveld van die bedryfsielkunde, het die verklaring en voorspelling, asook die beïnvloeding van verbruikergedrag as oogmerk (Pottas, 1975, p. 18). Terwyl die personeelsielkunde en die ergonomika primêr betrokke is by die gedrag van die individu as produsent, is die verbruikersielkunde betrokke by die gedrag van die individu as verbruiker. Voorheen is na die veld verwys as advertensiesielkunde veral in die boeke van pioniers soos Walter Dill Scott en H.L. Hollingworth. Waar die vroeër oriëntasie die klem laat val het op inligtingvloei van die produsent na die verbruiker, is die verbruikersielkunde meer onlangs uitgebrei ten einde ook tweerigtingkommunikasie tussen produsent en verbruiker in te sluit. Sistematiese ondersoeke na die behoeftes en motiewe van verbruikers is vir die eerste keer eers ná 1920 van stapel laat loop as 'n metode om sekere produkeienskappe waarin die verbruiker belang stel, te beklemtoon (Anastasi, 1964, 251).

\footnotetext{
* Tans by die Skool vir Bedryfsleiding, Universiteit van Suid-Afrika
} 
Die menslike geestesprosesse en die optredes waartoe dit lei, word beinvloed deur kognisies, dit wil sê, ons kennis beïnvloed ons gedrag. Kognisie of kennis bestaan uit idees, opvattinge, waarnemings, houdings, menings, waardes en gelowe. Markin (1974, 121) beskou die woord "kognisie" of kennis, nie as geskik om kennis in 'n verbruikersituasie te verteenwoordig nie. Beeld sou in werklikheid 'n beter begrip (konsep) wees, aangesien dit verwys na die verpersoonlike, geïnternaliseerde en gekonseptualiseerde begrip van wat ons weet. Beeld is subjektiewe kennis. Kennis impliseer geldigheid en waarheid. Beeld is dus die konnotasie wat ek glo om waar te wees. Verbruikers is geneig om vele beelde te skep. Hierdie beelde affekteer hul gedrag, houdings, waardes en predisposisies.

Beeld ontstaan as 'n geesteskonstruk na gelang van enkele geselekteerde indrukke uit die stroom van totale indrukke waarmee die verbruiker daagliks in aanraking kom. Dit ontstaan deur middel van 'n skeppende proses waarin geselekteerde indrukke uitgebrei, opgetooi en georden word (Markin, 1974, p.122). Beelde is gevolglik invloedsisteme wat aan (objektief verifieerbare) kennis verwant mag wees of nie mag wees nie. (Laasgenoemde veral waar subjektiewe waardeoordele die beeld voltooi.) Verbruikers skep beelde van winkels, artikels, handelsmerke en persone waarmee hulle in die mark te make kry. Dit is nie die objektiewe en feitelike wat selektiewe gedrag tot gevolg het nie, maar dit wat verbruikers subjektief dink of voel aangaande 'n produk, handelsmerk of organisasie.

Die vae en subjektiewe aard van die konsep (beeld) was tot dusver geensins bevorderlik vir die ontwikkeling van die kennis daaromtrent nie. Die twyfelagtige en vormlose aard van die konsep het die nut van menige studie baie verlaag.

Die probleem van hierdie ondersoek is dan ook in die eerste plek gesetel in die definiëring van die beeldkonsep in terme van 'n bedryfsielkundige benadering. Dit is van min waarde om die konsep te definieer indien die konstruk nie ook uiteindelik waarde het nie. In ons geval lê die waarde van die verbruikersielkundige konsep in die vermoë daarvan om menslike gedrag as verbruiker van goedere en dienste in ons moderne en gekompliseerde samelewing te kan verklaar.

Beeld in sy korrelasie met gedrag en instrumenteel tot gedrag, is dus ons veld van belangstelling.

In die literatuur word verskeie benaderings tot die konsep, beeld, aangetref. Die benaderings wissel van 'n persoonlikheidsbeskouing van die konsep aan die een kant tot 'n neiging om beeld as ' $n$ houding te definieer aan die ander kant. Deur die term verbruikerbeeld 
te gebruik, word die klem verskuif na die verbruiker en verbruikergedrag. In hierdie studie word verbruikerbeeld as 'n weerspieëling van die houding van 'n individu teenoor die organisasie gesien en dit bevat 'n sterk affektiewe, gedrags- en kognitiewe element.

Deur die beskouing van beeld as 'n funksie van houdings wat in oortuiginge gemanifesteer word, te huldig, beteken dat een van die talle houdingsmetingstegnieke vir ons doel van meting aangewend kan word. Die semantiese differensiaal wat deur Osgood (1952) as maatstaf van betekenis ontwikkel is, is reeds in talle soortgelyke gevalle ingespan met meer of minder sukses. In Suid-Afrika blyk daar 'n groot gebrek aangaande literatuur ten opsigte van beeld en beeldmeting te wees. Uit oorsese publikasies oor die konsep blyk dit dat beeldnavorsing in die verlede met vele kritiek te make gekry het. Daar word dan ook baie teenstrydighede in die literatuur aangetref. Afgesien van teenstrydighede in definiëring word die geldigheid van die meetmiddels in baie gevalle bevraagteken. Die konsep is by meer as een geleentheid gekritiseer as 'n stereotipe en dat response op een dimensie die response op die volgende dimensies van beeld kan voorspel (Tucker, 1961).

\section{NUT VAN DIE ONDERSOEK}

Beeldinligting kan vir een of meer van die volgende doelwitte aangewend word: (Mindak, 1961; Kelly en Stephensen,1964).

- Die onderneming kan deur beeldinligting kennis neem van die sukses of mislukking van sy huidige kommunikasiemetodes.

- $\quad$ Die prestasiegedrag van mededingers in die mark kan deur beeldinligting bekom word.

- Beeldinligting kan behulpsaam wees in die formulering van reklamestrategie.

- Opvolgstudies kan houdingsverandering jeens die organisasie weerspieël.

- $\quad$ Inligting wat voorheen vaag en onduidelik was en op subjektiewe raaiwerk berus het, word gekwantifiseer.

- Swak areas in die huidige reklame- of bemarkingsopset kan deur beeldinligting blootgelê, ontleed en herbeplan word.

Met ander woorde, die inligting deur beeldnavorsing bekom, kan gebruik word vir: 
- beplanning en reklamestrategie;

- effektiwiteitsevaluering en interne reorganisasie en

- $\quad$ as kommunikasiemedium vir beter wedersydse begrip tussen verbruiker en produsent.

Die vyf handelsbanke in Suid-Afrika wat by hierdie studie betrek is, is almal reeds goed gevestigde instellings wat geruime tyd reeds aktief in die volkshuishouding opereer. Al vyf hierdie banke, te wete Volkskas, Barclaysbank, Standardbank, Nedbank en die Trustbank, maak aktief van radio-, koerant- en tydskrifreklame gebruik.

Gevolglik behoort dit te verwagte te wees dat elkeen van hierdie organisasies met sekere houdinge, voorkeure, aksies, beleidsrigtings en groepe geassosieer sal word, dat elkeen unieke beeld by die verbruiker sal beskik en dat aspekte van hierdie beeld bepalend in sy keuse en of verandering van keuse van 'n handelsbank sal wees.

Indien 'n metode ontwikkel kan word wat tot die beskikking van hierdie organisasies gestel kan word, is die moontlikhede daarvan onbeperk. Dit maak deure tot marksegmentasie, herhaalde opvolgstudies en die evaluering van strategie op gereelde basis moontlik, mits die meetmiddel sodanig is dat dit hom daartoe leen.

Afgesien van al die suiwer tegniese moontlikhede van die studie bly die uiteindelike nut gesetel in die wese van die bedryfsielkundige benadering, naamlik dat 'n studie van hierdie aard ons kennis van die verbruiker in interaksie met sy omgewing en met die produsent van sekere essensiële dienste sal toelig. Dit kan slegs tot diens van ons samelewing wees aangesien die wedersydse begrip sowel die verbruiker as produsent sal stimuleer tot maksimale doeltreffendheid in die organisasie en ook tot die bevordering van verbruikertevredenheid.

\section{DOELSTELLING}

Die hipotese word gestel dat elke bank oor 'n unieke, gedifferensieerde verbruikerbeeld beskik wat uit sekere veralgemeenbare eienskappe bestaan wat nuttig in terme van die bemarkingsproses aangewend kan word.

Voordat hierdie hipotese ondersoek kan word, moet oorgegaan word tot die ontwikkeling van 'n maatstaf van handelsbankverbruikerbeeld in Suid-Afrika. Gevolglik bestaan die ondersoek uit twee fases. In die eerste fase word die metode waarvolgens die 
maatstaf ontwikkel is, bespreek, en in die tweede fase word die metode van toepassing van die gefinaliseerde maatstaf uiteengesit.

\section{METODE VAN ONDERSOEK}

\section{FASE 1}

\section{Die metingstegniek}

Daar is besluit om van 'n semantiese differensiaal as tegniek in die meting van verbruikerbeeld gebruik te maak, en wel om die volgende redes:

- In die sielkunde en bemarkingswese is die semantiese differensiaal as navorsingstegniek al dikwels met vrug benut. Die tegniek is oorspronklik deur Charles E. Osgood (1957) ontwikkel as 'n instrument om die konnotatiewe betekenisse van konsepte te meet. Die semantiese differensiasieproses lokaliseer die konnotatiewe betekenis van 'n konsep in 'n multidimensionele semantiese ruimte. Die term "semantiese differensiaal" verwys na enige versameling gradeerskale wat deur teenoorgestelde byvoeglike naamwoorde geanker is.

- $\quad$ Volgens Nunnally (1967, p.535) behoort die semantiese differensiaal nie as 'n spesifieke toets beskou word nie, maar as 'n baie buigbare benadering ten einde metings van houdings en ander sentimente te bekom. Volgens Nunnally kan feitlik enige konsep met behulp van 'n semantiese differensiaalskaal gradeer word, byvoorbeeld Winston Churchill, perskeroomys, vakbonde, motorkarre, ensovoorts. Dit is volgens Nunnally 'n uiters bruikbare metode vir die meet van houdings en ook verskillende fasette van houdings.

- Heelwat studies is reeds gedoen waar die semantiese differensiaal aangewend is om die houding van proefpersone jeens sekere konkrete en abstrakte objekte te bepaal. Een van Osgood se kollegas, Tannenbaum, was een van die eerste om 'n skaal saam te stel ten einde die houdings van persone jeens sekere konsepte te bepaal (Tannenbaum, 1956), alhoewel Stagner en Osgood (1946) reeds in 1946 die metode gebruik het om verandering in houdings jeens sekere stereotipes gedurende die Tweede Wêreldoorlog te meet. Meer onlangs, en nader aan die verbruikersielkunde, is die differensiaal ook nuttig aangewend deur Kjeldergaard (1961), Brinton (1961) en Barclay (1964) in die meet van houdings jeens objekte in die omgewing, terwyl Mindak (1961), Kunkel en 
Berry (1968), Bridwell (1968) Clevenger et.al. (1965) en Lamone (1967) enkeles was wat spesifiek daarin geïnteresserd was om verbruikerbeeld met behulp van die semantiese differensiaal te meet.

In wese bestaan die semantiese differensiaalmetode uit herhaalde beoordelings van die een of ander konsep teen pare beskrywende byvoeglike naamwoorde op 'n sewepuntskaal. Die aantal punte op die skaal varieer gewoonlik van 5 tot 9 , byvoorbeeld:

$$
\text { goed - - - - - sleg }
$$

Van die linkerkant af sal elk van die posisies op die skaal dus verteenwoordigend wees van uiters goed, baie goed, taamlik goed, gemiddeld, taamlik sleg, baie sleg en uiters sleg.

Die kenmerke van voorwerpe in ons omgewing word grootliks deur middel van byvoeglike naamwoorde in ons spreek- en skryftaal oorgedra. Die kenmerke van 'n persoon word gevolglik getipeer as vriendelik, saggeaard, intelligent, terwyl 'n regering se buitelandse beleid as oud-modies, stagnant of diskriminerend beskryf kan word. Dit kan geredelik aanvaar word dat die betekenis van dinge grootliks deur soortgelyke byvoeglike naamwoorde oorgedra word en dat hierdie woorde ook aangewend kan word om verskeie fasette van betekenis te meet. Die metode om teenoorgesteldes van byvoeglike naamwoorde as "ankers" van gradeerskale te gebruik, is gevolglik baie nuttig aangesien die meeste byvoeglike naamwoorde direkte teenoorgesteldes het.

Die primêre faktore word gewoonlik verteenwoordig deur die gradeerskale alhoewel daar in sommige studies deur middel van faktoranalise meer as drie faktore gevind is (Nunnally, 1967).

Die algemeenste faktor is dié van evaluasie wat gedefinieer word deur pare byvoeglike naamwoorde wat met 'n waarde-oordeel verband hou, byvoorbeeld:

$$
\text { goed - sleg eerlik - oneerlik }
$$

Die evaluasiefaktor is verreweg die sterkste faktor in semantiese differensiaalskale. Dit laat inderwaarheid min variasie oor vir definiering deur die ander faktore. Die negatiewepositiewe dimensie van betekenis word veral deur hierdie faktor ontleed en min byvoeglike naamwoorde beskik nie oor 'n negatiewe of positiewe element nie. Die evalueringsfaktor is dan ook dié een wat die term houding veral definieer. Skale wat verteenwoordigend is van die evaluasiefaktor behoort dus goed te dien as maatstaf van geverbaliseerde houdings.

Die tweede faktor is dié van potensie en hou verband met woorde soos: 
hard - sag

groot - klein

'n Derde faktor wat algemeen voorkom, is aktiwiteit en kan die volgende insluit:

aktief - passief vinnig - stadig

Dit is moeilik om skale te vind wat die laaste twee faktore duidelik meet. Gewoonlik korreleer selfs die beste skale vir die meet van potensie en aktiwiteit ook met die evalueringskale.

Opstel van die aanvanklike vraelys

'n Voorlopige vraelys is saamgestel deur semantiese differensiaalitems wat voorheen deur ander navorsers in beeldnavorsing gebruik is, saam te voeg.

Die gekeurde items is aangevul met enkele items wat eie aan Suid-Afrikaanse omstandighede behoort te wees. Die items is met behulp van taalkundiges in sowel Afrikaans as Engels so noukeurig moontlik gestel. Die items is met verantwoordelike bankamptenare bespreek en in enkele gevalle is van die items uitgelaat en/of aanvullings tot die lys gedoen. Die uiteindelike lys het uit 66 items bestaan.

\section{Die gegewens}

Die 66 aanvanklike items is in 'n tweetalige vraelys saamgevat en vir voltooiing aan 'n aantal proefpersone in Johannesburg en Pretoria gepos. 121 Vraelyste is uiteindelik verwerk. Die proefgroep het bestaan uit 50 bankamptenare (10 per bank) terwyl die res uit dosente, staatsdiensamptenare en derdejaar Unisa-studente bestaan het.

\section{Die faktoranalise}

Die gegewens is onderwerp aan 'n faktoranalise waaruit veertien onafhanklike faktore geisoleer is. Uit die faktore word die afleiding gemaak dat die proefpersone banke in terme van veertien dimensies evalueer wat soos volg omskryf is:

Faktor 1: Dinamiek

Faktor 2: Doeltreffendheid

Faktor 3: Lojaliteit

Faktor 4: Produktiwiteit

Faktor 5: Lokalisasie

Faktor 6: Verbruikergerigtheid

Faktor 7: Gebruikerassosiasie

Faktor 8: Gemeenskapsgerigtheid

Faktor 9: Atmosfeer 
Faktor 10: Geslagsverbintenis

Faktor 11: Fisiese aantreklikheid

Faktor 12: Finansiële toerekenbaarheid

Faktor 13: Prys van dienste

Faktor 14: Sekuriteit

\section{FASE II}

\section{Die finale vraelys}

Aan die hand van die statistiese gegewens uit die faktoranalise verkry, is die finale vraelys saamgestel met die volgende kenmerke:

- Slegs skale met ladings van $>0,70$ is vir die samestelling van die finale skale in aanmerking geneem.

- Negentien skale is uiteindelik geselekteer en in een vraelys onderaan die name van elk van die vyf handelsbanke aangebring. (Vergelyk Figuur 1).

- $\quad$ Die skale is verteenwoordigend van sewe van die veertien faktore wat deur die faktoranalise identifiseer is. Dié sewe is: dinamiek, doeltreffendheid, lojaliteit, produktiwiteit, gebruikerassosiasie, atmosfeer en prys van dienste.

- Die vraelys is van deeglike instruksies in albei landstale voorsien.

- Die volgende demografiese inligting is van elke proefpersoon aangevra: naam, adres, beroep, huistaal, geslag en of hy 'n kliënt van een van die betrokke handelsbanke is.

\section{Samestelling van die steekproef}

Die steekproef is saamgestel deur gebruik te maak van die "Rand and Pretoria Directory" van 1974. Uit die afdeling vir Pretoriase straatadresse, is 750 name op ewekansige wyse getrek en aan elke persoon 'n vraelys gepos. Die vraelyste is in Augustus 1975 uitgestuur.

Van die 750 vraelyste is 159 terugontvang, dit wil sê, $21,2 \%$ van die aanvanklike steekproef. Van die 159 kon egter slegs 103 vraelyste gebruik word, vanweë foute wat deur proefpersone gemaak is en wat kodering van die inligting onmoontlik gemaak het. Die finale proefgroep verteenwoordig dus $13,73 \%$ van die oorspronklike proefgroep. 


\begin{tabular}{|c|c|c|c|}
\hline 1. & dinamies/dynamic & -------- & staties/static \\
\hline 2. & $\begin{array}{l}\text { verbeeldingryk } \\
\text { imaginative }\end{array}$ & ------- & $\begin{array}{l}\text { verbeeldingloos } \\
\text { unimaginative }\end{array}$ \\
\hline 3. & modern/modern & --------- & oud-modies/old fashioned \\
\hline 4. & aktieflactive & -------- & passief/passive \\
\hline 5. & $\begin{array}{l}\text { aantreklik } \\
\text { attarctive }\end{array}$ & -------- & $\begin{array}{l}\text { onaantreklik } \\
\text { unattractive }\end{array}$ \\
\hline 6. & $\begin{array}{l}\text { opwindend } \\
\text { exiting }\end{array}$ & -------- & $\begin{array}{l}\text { vervelig } \\
\text { boring }\end{array}$ \\
\hline 7. & $\begin{array}{l}\text { progressief } \\
\text { progressive }\end{array}$ & --------- & $\begin{array}{l}\text { stagnant } \\
\text { unprogressive }\end{array}$ \\
\hline 8. & $\begin{array}{l}\text { unieke dienste } \\
\text { unique services }\end{array}$ & --------- & $\begin{array}{l}\text { slegs gewone dienste } \\
\text { only the usual services }\end{array}$ \\
\hline 9. & $\begin{array}{l}\text { groei vinnig } \\
\text { growing fast }\end{array}$ & --------- & $\begin{array}{l}\text { groei stadig } \\
\text { growing slowly }\end{array}$ \\
\hline 10. & deeglik/thorough & --------- & nalatig/negligent \\
\hline 11. & $\begin{array}{l}\text { effektief } \\
\text { effective }\end{array}$ & -------- & $\begin{array}{l}\text { oneffektief } \\
\text { ineffective }\end{array}$ \\
\hline 12. & $\begin{array}{l}\text { betroubaar } \\
\text { reliable }\end{array}$ & -------- & $\begin{array}{l}\text { onbetroubaar } \\
\text { unreliable }\end{array}$ \\
\hline 13. & $\begin{array}{l}\text { versigtig } \\
\text { careful }\end{array}$ & --------- & $\begin{array}{l}\text { agterlosig } \\
\text { careless }\end{array}$ \\
\hline 14. & $\begin{array}{l}\text { patrioties } \\
\text { patriotic }\end{array}$ & --------- & $\begin{array}{l}\text { onpatrioties } \\
\text { unpatriotic }\end{array}$ \\
\hline 15. & Afrikaans & --------- & Engels/English \\
\hline 16. & $\begin{array}{l}\text { baie dienste } \\
\text { many services }\end{array}$ & -------- & $\begin{array}{l}\text { min dienste } \\
\text { few services }\end{array}$ \\
\hline 17. & $\begin{array}{l}\text { gesofistikeerd } \\
\text { sophisticated }\end{array}$ & --------- & $\begin{array}{l}\text { ongesofistikeerd } \\
\text { unsophisticated }\end{array}$ \\
\hline 18. & $\begin{array}{l}\text { informeel } \\
\text { informal }\end{array}$ & -------- & $\begin{array}{l}\text { formeel } \\
\text { formal }\end{array}$ \\
\hline 19. & $\begin{array}{l}\text { nie duur nie } \\
\text { inexpensive }\end{array}$ & --------- & $\begin{array}{l}\text { duur } \\
\text { expensive }\end{array}$ \\
\hline
\end{tabular}

Figuur 1. Lys van skale in finale vraelys opgeneem 


\section{Verwerking van gegewens}

Vir die doel van die hipotese van die ondersoek is die volgende verwerkings uitgevoer: Ten einde 'n profiel van elke bankinstelling te kan saamstel en die betekenisvolheid van verskille binne groepe te kon evalueer, is rekenkundige gemiddeldes $(\bar{X})$ asook standaardafwykings $(\mathrm{s})$ en variansies $\left(\mathrm{s}^{2}\right)$ per skaal per bank ondersoek.

Om te kon bepaal of die verskille binne die groepe betekenisvol is al dan nie, is eenrigtingvariansie-ontledings uitgevoer. Betekenisvolle verskille bestaan in hierdie geval waar F >2,4 (Winer, 1971, p.868). Aangesien 'n betekenisvolle F-waarde slegs 'n aanduiding gee dat daar wel betekenisvolle verskille tussen twee of meer van die banke op die spesifieke skaal bestaan, is die lokalisasie van die verskille verder ontleed deur gebruik te maak van die meervoudige vergelykingstoets van Scheffé.

Die Scheffé-metode is volgens Ferguson (1966, p.297) maklik om toe te pas en word nie ernstig beïnvloed deur aannames van normaliteit en homogeniteit van variansies nie, behalwe as die variansieverskille baie groot is. Aangesien A-posteriori-hipoteses ondersoek word, d.w.s. die rigtings van verskil word nie vooraf gestel nie, is F-waardes vir betekenisvolheid op die $5 \%$ en $1 \%$ vlak ten opsigte van die meervoudige vergelykingstoets van Scheffé in hierdie geval onderskeidelik 9,56 en 13,44.

In die laaste fase van die ondersoek is 'n meervoudige groep diskriminantanalise (Unisa-rekensentrum, 1975) uitgevoer. Die doel van hierdie analise is om te bepaal of elke bank 'n unieke profiel het. Dit is 'n kragtige metode om elke beeld van elke handelsbank te toets en is 'n finale aanduiding van die ware onafhanklikheid van verbruikerbeeld van elke handelsbank.

Aangesien die inligting wat uit die vraelyste voortspruit, tot die nadeel van sommige van die handelsbanke mag strek, word aan elk van die instellings met 'n kode aangedui. Daar word dus vir die doeleindes van die res van die bespreking na banke 1, 2, 3, 4 en 5 verwys. Dié volgorde is op ewekansige basis aan elke bank toegeken.

\section{Resultate en gevolgtrekkings}

In hierdie studie is die volgende vasgestel:

- $\quad$ Ten opsigte van die dinamiekfaktor (items 1 tot 9) het bank 4 ten opsigte van elke item 'n hoër gradering gekry. Bank 4 is dus dinamieser, verbeeldingryker, moderner, aktiewer, aantrekliker (behalwe as bank 2), opwindender en progressiewer, met unieker 
dienste en besig om vinniger te groei as enige van die ander vier mededingers. Banke 2 en 3 is dinamieser as bank 5, asook verbeeldingryker as bank 5. Bank 5 is ook minder verbeeldingryk as bank 1. Bank 2 is moderner as banke 1, 3 en 5 . Bank 3 is ook moderner as bank 5, wat dus die mees oud-modiese bank is. So is bank 5 ook onaantrekliker as banke 2 en 4 . Bank 2 lê deurgaans tweede op al die skale in die dinamiek-dimensie en word as opwindender as minstens bank 5 beskou. Laasgenoemde is ook verveliger as bank 3. Bank 5 blyk ook, afgesien van bank 4, meer stagnant te wees as bank 2. Laasgenoemde het unieker dienste as bank 5.

- $\quad$ Met betrekking tot die doeltreffendheidsdimensie, word bank 4 deurgaans as die mins doeltreffende bank beskou. Bank 4 is dus nalatiger as sy mededingers, minder effektief as banke 1, 3 en 5, minder betroubaar en agtelosiger as enige van die ander vier banke. Op die lojaliteitsdimensie (skale 14 en 15) word bank 5 as die mees patriotiese en die mees Afrikaanse beskou. Bank 4 is betekenisvol meer patrioties as bank 2 en meer patrioties as bank 1. Wat die skaal Afrikaans - Engels betref, verskil al die banke betekenisvol. Bank 1 is die meeste Engels en bank 3 die tweede meeste. Bank 2 is meer Afrikaans as Engels, maar nie soveel soos banke 5 en 4 nie.

Ten opsigte van die produktiwiteitsdimensie is Bank 4 die enigste wat betekenisvol meer dienste het as die ander banke.

- $\quad$ Met betrekking tot die kliënte-assosiasiefaktor is daar slegs een beduidende verskil. Bank 4 word as gesofistikeerder as bank 5 beskou.

- Die tweede laaste faktor is dié van atmosfeer. Bank 4 word as minder formeel as banke 1,3 en 5 beskou. Bank 1 is dus ook formeler as bank 2 .

- Die dimensie prys van dienste, en die skaal nie duur nie, toon geen betekenisvolle verskille tussen enige van die banke nie. Dit is duidelik dat die verskille hier toevallig is. Hieruit kan afgelei word dat die koste-aspek by banke moontlik belangrik mag wees, maar nie determinerend ten opsigte van potensiële verbruikergedrag jeens die banke nie. Met ander woorde, die koste-aspek speel geen werklike rol by die verbruiker in sy keuse van 'n handelsbank nie.

- Die resultate is grafies as 'n verbruikerbeeldprofiel voorgestel (Figuur 2). Aangesien al die banke op een profiel aangebring is, kan die relatiewe posisie van elke bank ten opsigte van elke skaal onmiddellik waargeneem word. Dit behoort die profiel 'n nuttige werkstuk in die hande van die bemarkingsbestuurder te maak. 
Uit die profiel kan die volgende veralgemeende beskrywings van elke bank afgelei word:

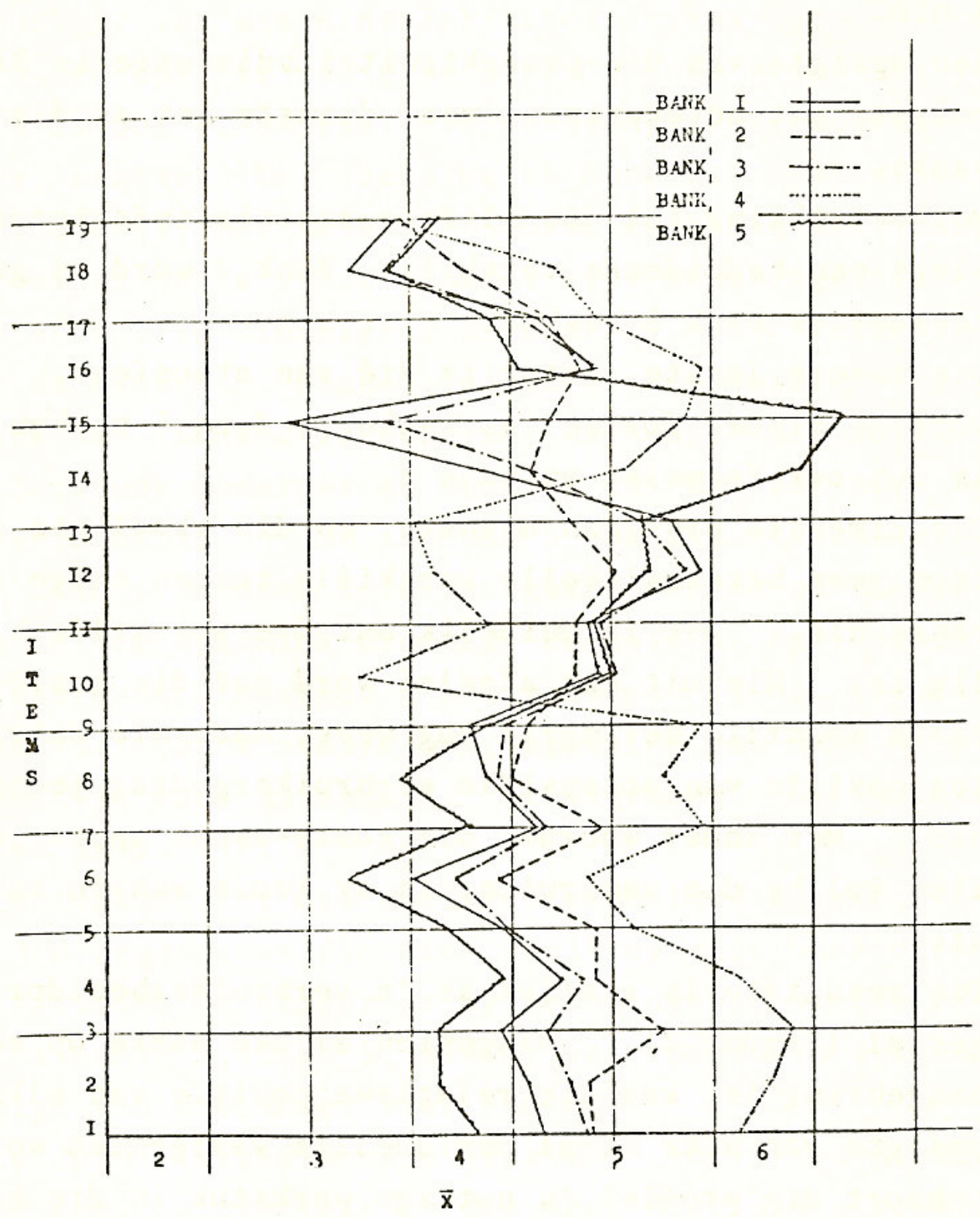

Figuur 2. Die verbruikerbeeldprofie1 


\section{Bank 1}

Bank 1 is ook besonder deeglik en effektief en betroubaarder as enige van sy mededingers wat hom in die algemeen as van die doeltreffendste bankinstellings klassifiseer. Hy stel nie besondere patriotisme ten toon nie en is die mees Engelse bank in Suid-Afrika. Hy is ook baie formeel en wat gesofistikeerdheid betref, is daar min tussen hom en die mededingers te kies.

\section{Bank 2}

Bank 2 is ' $n$ baie dinamiese bank. Op een na is hy die mees dinamiese, verbeeldingrykste, modernste, aktiefste, opwindendste, progressiefste, uniekste (ten opsigte van dienste) en vinnigste groeiende. Wat deeglikheid en algemene doeltreffendheid betref, is daar min tussen hom en die bestes te kies. Met betrekking tot lojaliteit is hy betreklik neutraal - moontlik effens aan die Afrikaanse kant en verder is hy nie formeel nie maar ook nie informeel nie, beskik oor bogemiddelde aantal dienste en is van bogemiddelde gesofistikeerdheid.

\section{Bank 3}

Bank 3 is 'n gemiddelde bank. Hy is in baie opsigte die bank in die middel, behalwe dat hy meer na die Engelse kant toe neig en dat hy as baie betroubaar, doeltreffend en bogemiddeld aktief beskou word.

\section{Bank 4}

Bank 4 is 'n bank van uiterstes. Dié bank is sonder uitsondering die mees dinamiese, progressiefste, verbeeldingrykste, modernste, aantreklikste, opwindendste bank met die uniekste dienste. Hy groei ook die vinnigste. In teenstelling hiermee is hy die heel nalatigste bank en is baie meer oneffektief, onbetroubaar en agtelosig as enige mededinger en is baie informeel. Nogtans is dit ' $\mathrm{n}$ Afrikaanse bank wat as patrioties en betreklik gesofistikeerd beskou word, met meer dienste as enige konkurrent in die handelsbankmark.

\section{Bank 5}

Bank 5 is 'n bank met 'n lae dinamiek, relatief tot die ander, alhoewel nog nie ver onder 'n suiwer gemiddelde nie. Dis 'n vervelige bank met slegs gewone dienste. In teenstelling hiermee is hy net so doeltreffend soos sy mededingers. 
Hy is verreweg die mees patriotiese bankinstelling en uit en uit Afirkaans. Nogtans bied dit minder dienste as sy mededingers, is ongesofistikeerder as die konkurrente, maar verskil nie ten opsigte van formaliteit nie.

Met behulp van 'n diskriminantanalise is die onafhanklikheid en uniekheid van die verbruikerbeeld van elke handelsbank gedemonstreer. In Tabel 1 word die resultate daarvan weergegee. Die bank met die duidelikste verbruikerbeeld is bank 5, aangesien hy deur 88 van die proefpersone op 'n wyse soortgelyk aan die verbruikerbeeld van bank 5 beoordeel is. ' $n$ Mate van twyfel bestaan oor bank 3. Drie-en-veertig proefpersone se beoordelings van bank 3 kom ooreen met die verbruikerbeeld van bank 3, maar 32 beoordelings kom in werklikheid met die beeld van bank 1 ooreen, terwyl 20 proefpersone ' $n$ evaluasie nader aan bank 2 tydens hulle evaluasie van bank 3 neergeskryf het. Daar mag dus sprake wees van 'n mate van stimulusveralgemening tussen banke 1 en 3 .

- Banke in Suid-Afrika word die algemeenste onder dimensies van dinamiek, doeltreffendheid en lojaliteit beoordeel deur die verbruikerpubliek. Die skaal AfrikaansEngels blyk die mees sensitiewe skaal te wees en het ook die grootste en betkenisvolste verskille getoon.

- $\quad$ 'n Maatstaf van verbruikerbeeld van handelsbanke is hiermee ontwikkel wat heelwat prakties uitvoerbare moontlikhede inhou. Die bank se sterk en swak punte kan onmiddellik raakgesien word en so ook die van die mededingers. Huidige kommunikasiedoelwitte kan aan die hand van die inligting opgeweeg word. Die metode kan herhaaldelik en in andersoortige situasies of segmente toegepas word ten einde houdingsveranderinge en/of verbruikerbeeld onder spesifieke segmente van die mark vas te stel.

\section{SLOT}

Deur middel van hierdie ondersoek word aangetoon dat daar aanduidings is dat daar vir elke handelsbank in Suid-Afrika 'n unieke en andersoortige verbruikerbeeld bestaan. Verder word aangetoon dat hierdie banke regstreeks of onregstreeks met sekere eienskappe en groepe geassosieer word.

Die verbruiker neem in groot mate dinge uit sy omgewing op selektiewe wyse waar. By banke is dit ook nie anders nie. Die persoonlike vooroordele is waarskynlik in groot mate ongegrond ten opsigte van vele van die aspekte wat onder die vergrootglas geplaas is, maar 


\section{TABEL 1}

\section{RESULTATE VAN DIE DISKRIMINANT-ANALISE}

\begin{tabular}{|c|c|c|}
\hline Bank & $\begin{array}{c}\text { Verwagte } \\
\text { bank }\end{array}$ & $\begin{array}{c}\text { Getal } \\
\text { proefpersone }\end{array}$ \\
\hline 1 & $\begin{array}{l}1 \\
2 \\
3 \\
4 \\
5\end{array}$ & $\begin{array}{c}63 \\
14 \\
23 \\
2 \\
1\end{array}$ \\
\hline 2 & $\begin{array}{l}1 \\
2 \\
3 \\
4 \\
5\end{array}$ & $\begin{array}{c}5 \\
68 \\
15 \\
6 \\
9\end{array}$ \\
\hline 3 & $\begin{array}{l}1 \\
2 \\
3 \\
4 \\
5\end{array}$ & $\begin{array}{c}32 \\
20 \\
43 \\
4 \\
4\end{array}$ \\
\hline 4 & $\begin{array}{l}1 \\
2 \\
3 \\
4 \\
5\end{array}$ & $\begin{array}{c}1 \\
9 \\
2 \\
3 \\
88\end{array}$ \\
\hline 5 & $\begin{array}{l}1 \\
2 \\
3 \\
4 \\
5\end{array}$ & $\begin{array}{c}1 \\
9 \\
2 \\
3 \\
88\end{array}$ \\
\hline
\end{tabular}

die beeldkonsep dien as indrukwekkende illustrasie van die geweldige tempo waarteen inligting, selfs betreffende sake soos banke, in die verbruikermark versprei.

Newe-inligting wat uit die ondersoek geblyk het, het dit onder meer duidelik gemaak dat daar heelwat moontlikhede vir verdere navorsing ten opsigte van beeld en verwante aspekte bestaan. Die veld lê nog braak vir sover dit navorsing van hierdie aard betref.

*Die waarde van hierdie navorsing lê waarskynlik meer op die metodologiese vlak waar dit 'n aantal riglyne neerlê vir verbruikerbeeldnavorsing, veral met betrekking tot handelsbanke in Suid-Afrika. Die bevindinge moet egter as tentatief beskou word aangesien slegs

\footnotetext{
Redaksionele kommentaar 
$13,73 \%$ van die oorspronklike ewekansige steekproef aan die navorsing deelgeneem het. Daarbenewens was dit in hierdie navorsingsopset nie prakties om onderskeid te tref tussen verskillende marksegmente nie sodat dit ook nie vasgestel kon word of positiewe of negatiewe beelde deur werklike verbruikers of potensiële verbruikers van 'n bepaalde bank, nagehou word nie.

\section{OPSOMMING}

In hierdie ondersoek word die hipotese gestel dat elke handelsbank oor 'n unieke en gedifferensieerde verbruikerbeeld beskik. Deur middel van 'n faktoranalitiese ondersoek word 'n semantiese differensiaal ontwikkel ten einde verbruikerbeeldskale op verskillende faktore daar te stel vir die verkryging van 'n spektrum van verbruikerevaluasies van elke bank. Uit die resultate word vasgestel dat handelsbanke in terme van 14 dimensies evalueer word. Die hipotese wat in die toekoms ten opsigte van talle navorsingsoogmerke aangewend kan word.

\section{VERWYSINGS}

Anastasi, A. Field of Applied Psychology. McGraw-Hill, 1964.

Barclay, W.D. The semantic differential as an index of brand attitude. Journal of Advertising Research, 1964, 4, 30-33.

Birdwell, E.A. A study of the influence of image congruence on consumer choice. Journal of Business, January 1968, XLI(1), 76-88.

Brinton, J.E. Deriving an attitude scale from semantic differential data. Public Opinion Quarterly, Summer 1961, 25, 289-295.

Clevenger, T. (jr.), Lazier, G.A. \& Clark, M.L. Measurement of corporate images by the semantic differential. Journal of Marketing Research, February 1965, 2, 80-82.

Ferguson, G.A. Statistical Analysis in Psychology and Education. N.York: McGraw-Hill, 1966.

Kelly, R.F. \& Stephenson, R. The semantic differential: an information source for designing retail patronage appeals. Journal of Marketing, 1964, 31, 43-47.

Kjeldergaard, P.M. Attitudes towards newscasters as measured by the semantic differential. Journal of Applied Psychology, 1961, 45(1), 35-40.

Kunkel, J.B. \& Berry, L.L. A behavioural conception of retail image. Journal of Marketing, October 1968, 32, 21-27.

Lamone, R.P. The Use of the Semantic Differential in a Study of Self-image, Product Image and Prediction of Consumer Choice. Ph.D. thesis, University of North Carolina, 1967.

Markin, R.J. (jr.) Consumer Behaviour, New York: MacMillan, 1974.

Mindak, W.A. Fitting the semantic differential to the marketing problem. Journal of Marketing, 1961, 25, 28-33.

Nunnally, J.C. Psychometric Theory. McGraw-Hill, 1967.

Osgood, C.E. The nature and measurement of meaning. Psychological Bulletin, 1952, 49(3), 197-237. 
Osgood, C.E., Suci, G. \& Tannenbaum, P. The Measurement of Meaning. University of Illinois Press, 1957.

Pottas, C.D. Persoonlikheidskorrelate van Kognitiewe Dissonansie in Verbruikersgedrag. D.Phil.-proefskrif, R.A.U., 1975.

Stagner, R. \& Osgood, C.E. Impact of war on a nationalistic frame of reference: changes in general approval and qualitative patterning of certain stereotypes. Journal of Social Psychology, 1946, 24, 187-215.

Tannenbaum, P.H. Initial attitude toward source and concept as factors in attitude change through communication. Public Opinion Quarterly, 1956, 20, 413-425.

Tucker, W.T. How much of the corporate image is stereotype. Journal of Marketing, January 1961, 61-65.

Unisa Rekensentrum, 1975.

Winer, B.J. Statistical Principles in Experimental Design. 2nd Ed., McGraw-Hill, 1971. 
